\title{
Exploring Student Perceptions of Flipgrid in Online Courses
}

\author{
Patrick R. Lowenthal \\ Boise State University \\ Robert L. Moore \\ Old Dominion University
}

\begin{abstract}
Asynchronous video-based discussions have affordances that can address some of the constraints of asynchronous text-based discussions. However, little research has been conducted on the use of asynchronous video-based discussions in online courses. As a result, the purpose of this exploratory study was to investigate students' perceptions of using Flipgrid for asynchronous video-based discussions in fully online courses. We used a cross-sectional survey design to survey 79 students who used Flipgrid in a fully online course. Students overall reported that they liked using Flipgrid, it was easy to use, and that it helped improve social presence. In this paper, we will report the results of our inquiry and implications for research and practice.
\end{abstract}

Keywords: video, asynchronous video, interaction, online discussions, social presence, classroom community, Flipgrid

Lowenthal, P.R., \& Moore., R.L. (2020). Exploring student perceptions of Flipgrid in online courses. Online Learning, 24(4), 28-41. https://doi.org/10.24059/olj.v24i4.2335

\section{Exploring Student Perceptions of Flipgrid in Online Courses}

The first online course was offered over 30 years ago (Harasim, 1987). However, despite advances in technology in the decades since, the main ways that instructors and students interact with each other in online courses, as well as the challenges that these methods of interaction present, have changed very little. Asynchronous text-based discussions are still the main way that instructors and students interact in online courses today (Arend, 2009; Guo, Chen, \& Hou, 2019; Maddix, 2012; Moore, 2016; Serembus \& Murphy, 2020). Thus, while the development of learning management systems (LMS), various educational technologies, and approaches to designing online instruction have evolved - andÍ arguably even matured - in many ways, the typical online course today centers around the same type of asynchronous text-based discussions used over the past 30 years. 
There is good reason why online learning today centers around asynchronous text-based discussions. Asynchronous text-based discussions are versatile and can be very effective for teaching and learning in online learning environments. For instance, asynchronous text-based discussions enable learners to interact with each other, course content, and their instructors at their own time and place - a hallmark of distance education (Aloni \& Harrington, 2018; Moore, 2016; Poll et al., 2014). Research has also shown that they can promote reflection, encourage equitable participation, and foster the development of learning communities for students (Arend, 2009; Hrastinski, 2008; Johnson, 2008; Maddix, 2012), which in turn can help decrease feelings of isolation or disconnectedness that can be common among online learners (Kaufmann \& Vallade, 2020; Rourke, Anderson, Garrison, \& Archer, 1999).

However, despite affordances like these, asynchronous text-based communication in general has some inherent constraints. For instance, asynchronous text-based communication has been criticized, almost since its inception, for being impersonal and antisocial, largely because of the cues filtered out, and therefore only good at task-oriented communication (Lowenthal, 2010). Stodel, Thompson, and MacDonald (2006) concluded that "threaded discussions can make it hard to inject emotion into communication, make others salient in the learning environment, and foster enjoyable and rewarding interactions" (p. 19). Further, these text-based discussions lack the social cues, such as voice inflections and non-verbal gesturing, that are critical to interpreting and understanding meaning (Gurjar, 2020; Serembus \& Murphy, 2020). Other research has shown that students can get frustrated with the inherent delay and lack of immediacy in asynchronous discussions (Doherty, 2006; Meyer, 2003; Song et al., 2004). Thus, asynchronous text-based discussions may not be inclusive or effective for all students (Green \& Green, 2018) and can often end up feeling like busy work to students. Constraints of asynchronous text-based communication, such as these, are often used to explain the high rates of attrition and why many students might not learn successfully in online courses (Ludwig-Hardman \& Dunlap, 2003; Richardson, Maeda, Lv, \& Caskurlu, 2017).

Research suggests that if students are able to interact and communicate better with each other, they can then develop a stronger sense of social presence and classroom community, which can help them persist and be more successful in their online courses (Boston et al., 2009; Boston et al., 2011; Garrett Dikkers, Whiteside, \& Lewis, 2012; Gurjar, 2020; Moore; 2014; Picciano, 2002; Rovai, 2002; Whiteside, 2015; Whiteside, Garrett Dikkers, \& Lewis, 2014). Given this, some online educators have focused on identifying ways to improve the use of asynchronous textbased communication in online courses - recognizing that many criticisms of it might be more about how we use them than the technology itself (Johnson, 2016; Kwon, Park, Shin, \& Chang, 2019; Woods \& Bliss, 2016). At time same time, others have investigated how technological advances, such as asynchronous video, might provide new ways for students to interact and communicate with each other (Delmas \& Moore, 2019; Gurjar, 2020; Oliver, Moore, \& Evans, 2017; Serembus \& Murphy, 2020). However, questions remain about whether asynchronous video-based discussions in particular can address the problems students have with asynchronous text-based discussions (Lowenthal, Borup, West, \& Archambault, 2020; Saçak \& Kavun, 2020). As a result, the purpose of this study was to investigate student perceptions of using asynchronous video discussions, specifically Flipgrid, in online courses. In the following paper, we will report the results of our inquiry and implications for future research and practice. 


\section{Review of Relevant Literature}

Asynchronous video-based discussions can enable online educators to leverage some of the affordances of asynchronous communication (e.g., being able to interact and communicate at a time and place that is convenient) and video communication (e.g., visually rich, nonverbal) at the same time (Lowenthal, West, Archambault, \& Borup, 2020). This type of communication involves someone recording a short video (e.g., with a webcam on a computer or with a phone) and then sharing with others to watch on their own time, and if they like, comment or respond to the video in some way. Early on this was often done by uploading a short video to a learning management system where others could respond with a text-reply in a discussion forum or by uploading the video to a video server (e.g., YouTube) where others could comment or add annotations to the video (see Howard \& Myers, 2010; Lowenthal \& Mulder, 2017). However, during the past few years, applications like VoiceThread and Flipgrid have been developed that enable instructors and students to create and share asynchronous video in a seamless way. While both tools are relatively new, there have been some promising applications reported across educational contexts. Some initial research to date has found that students prefer video-based discussions over text-based discussions (Clark, Strudler, \& Grove, 2015; Skylar, 2009). Group cohesion, a key indicator of social presence (see Rourke et al., 1999), in particular has been found to be increased through the use of online video discussions (Pinsk, Curran, Poirier, \& Coulson, 2014). Research also has shown that video-based discussions can improve connections between instructors and students (Moore, 2016; Romero-Hall \& Vicentini, 2017).

Four common applications used for asynchronous video-based discussions today are: VoiceThread, Flipgird, EdConnect, and Marco Polo (Lowenthal et al., 2020). However, research to date has focused largely on VoiceThread and to a lesser degree Flipgrid. VoiceThread enables users to narrate and record presentations and then discuss these presentations using multimodal commenting tools (Ching, 2014; Dunlap \& Lowenthal, 2011; Oliver et al., 2017). Online educators have been interested in using VoiceThread for multimodal discussions because of the potential of multimodal communication to "humanize" online discussions (Ching \& Hsu, 2013; Koricich, 2013; Pacansky-Brock, 2012, 2014; Trespalacios \& Rand, 2015). In one study, Borup, West, and Graham (2012) investigated student perceptions of asynchronous video using VoiceThread or YouTube. They found that asynchronous video helped establish an instructor's social presence but that it had less of an impact on establishing social presence of students. In a follow-up study, Borup et al. (2013) found that the type of discussion prompt influenced students' perceptions of asynchronous video. In another study, Pacansky-Brock (2014) investigated students' use of video commenting in VoiceThread. She was able to increase the number of video comments in VoiceThread by (a) using a VoiceThread icebreaker early in the course, (b) requiring students to leave a voice or video comment the first time they used VoiceThread in the course, (c) providing choices about what students will respond to, and (d) welcoming students by name to comment on the VoiceThread (Pacansky-Brock, 2014). Participants in Pacansky-Brock's study reported stronger perceptions of community and improved emotion when leaving voice or video comments instead of text-only comments.

Flipgrid and VoiceThread allow for interaction and collaboration between students in a way that is not possible with text-based discussions (Saçak \& Kavun, 2020). Flipgrid, though, differs in some important ways from VoiceThread. First, it is an application meant for asynchronous video-based discussions. While VoiceThread allows for a variety of media to be uploaded (e.g., images, video, PowerPoint slides), Flipgrid is completely video-based. Students 
post a video response and then can reply to instructor or peer videos with their own videos. Researchers have examined the use of Flipgrid in language classes (Mango, 2019), undergraduate agribusiness law courses (Hall, 2015), public speaking courses (Gerbensky-Kerber, 2017), and for video reflections as part of makerspace activities (Oliver, Houchins, Moore, \& Wang, 2020). In one study, Delmas and Moore (2019) explored the use of Flipgrid in undergraduate and graduate classes and students reported that they felt that their feelings of community and connection were made stronger using Flipgrid. Additionally, the use of Flipgrid may support the development of the three presences that make up the Community of Inquiry (Gurjar, 2020; Serembus \& Murphy, 2020). Flipgrid, and the asynchronous video-based discussions it supports, allow students to interact and engage with each other in ways not possible before, which can in turn help increase social presence in online courses (Green \& Green, 2018; Jones-Roberts, 2018; Mahmoudi \& Gronseth, 2019; Moore, 2016; Gurjar 2020; Serembus \& Murphy, 2020). In an online course, there can be feelings of isolation, and the use of video can cut that transactional distance and foster connections between students. Cognitive presence can be supported using video replies and the interaction that occurs between both peers and the instructor (Serembus \& Murphy, 2020). The ability to reply to each other's videos is a newer feature in Flipgrid and its integration has increased the potential applications for learning. Like threaded discussion forums, Flipgrid seamlessly creates threaded comments and allows for short video replies between students. And finally, teaching presence is supported through Flipgrid by hosting collaboration between peers and instructors (Serembus \& Murphy, 2020). Thurs, research suggests that instructors can use Flipgrid as a tool to support the type of collaboration and engagement that they are seeking in their online courses (Gurjar, 2020; Mejia, 2020; Moore, 2016). Comparatively, though, very little research, has been conducted on Flipgrid to date.

\section{Method}

Given the need to improve interaction and communication in online courses, the purported affordances of asynchronous video-based discussions, and the lack of research on Flipgrid in particular, we conducted an exploratory study of students' perceptions of using Flipgrid in three fully online graduate courses. We used a cross-sectional survey design (Glasow, 2005) to answer the following research question: What are student perceptions of using Flipgrid in fully online courses?

A survey consisting of quantitative Likert-style questions and qualitative open-ended questions was constructed to answer the research question guiding this study. As an exploratory study focused on student perceptions of a communication technology, the survey questions included some basic demographic questions and then questions focused on students' perceptions of using Flipgrid and whether they would use it as educators in the courses they teach.

The participants came from three different graduate courses offered in a fully online educational technology program taught by the same instructor over an academic year. The majority of students in this program were full-time educators (either in K12 or higher education) or instructional designers. Students in the courses used Flipgrid for an initial meet-and-greet asynchronous video-based discussion where they introduced themselves to their peers and responded to their peers' posts. Then later in each course, students used Flipgrid for an asynchronous video-based discussion; for instance, in one course, students had to define educational technology in two minutes or less and then respond to their peers' posts. The survey 
was administered during the last week of each course. A total of 79 out of 82 students took part in the study, for a response rate of $96 \%$.

The results were downloaded into a spreadsheet and analyzed. Descriptive statistics were calculated for the Likert-style questions, and the qualitative data from the open-ended questions was analyzed using a constant comparative technique (Leech \& Onwuegbuzie, 2007). This involved using a multistage coding process of descriptive and pattern coding to code and analyze the open-ended responses (Saldana, 2016).

\section{Results}

In general, the students in this study liked Flipgrid. When asked if they liked using Flipgrid, the average response was 3.17 on a 0 to 4 scale $(4=$ strongly agree, $0=$ strongly disagree), with the majority of respondents agreeing or strongly agreeing that they liked it. When specifically asked what they liked about using Flipgrid, some themes emerged from their responses. Students consistently stated that they liked how easy Flipgrid was to use, how they liked connecting a face with a name, and that they liked having the ability to see and hear their classmates as captured by the following quotes:

- I don't generally like being in videos, but Flipgrid feels different. It is the closest that I have ever felt like I was having a face-to-face conversation with another person in an asynchronous setting. I think that feeling stems from the ease of use.

- Being able to see (and hear) each other as actual people behind computers.

- I love Flipgrid and use it with my own students every week. I'm actually a Flipgrid ambassador, so I'm an easy sell on its value. Having rich video discussions is so much more impactful and engaging than reading yet another discussion board post.

- I love Flipgrid. It felt easier to have a conversation using this platform as opposed to the online discussions. I felt more connected in this space to peers. In addition, I could respond using my phone. With the online discussions I would have to use my laptop.

We were also interested in what students might dislike about Flipgrid. As illustrated in Table 1, some people simply did not like Flipgrid and therefore disliked everything about it. At the same time, the majority liked Flipgrid and therefore, not surprisingly, responded that there was nothing they disliked about Flipgrid. However, there were still others who reported that they liked Flipgrid but found things about Flipgrid that they did not like. For these students, the most frequent theme that emerged about what they disliked was their unease with recording themselves. Some pointed out that they disliked that they felt a need to make the video perfect, and some others pointed out that they struggled following conversations in Flipgrid. At the same time, some said that they disliked that Flipgrid was not used more in the courses. The following quotes captures some of these sentiments:

- I have self-confidence issues and really hate being in video.

- Having to look presentable.

- Showing too much of oneself.

- I can be uneasy on video, and can sometimes take multiple trials to submit something worthwhile. 
- I couldn't reply to my replies.

To better understand how much students (who were predominantly teachers) liked Flipgrid, we asked them how likely they would be to use Flipgrid in an online course they were teaching and then to explain why they answered the way that they did. Over $75 \%$ responded that they would likely or very likely use Flipgrid in a course they were teaching. And when specifically asked if they would rather simply use text-based asynchronous discussions, over $61 \%$ essentially responded that they would not (see Table 1). Responses varied on why they would likely or not likely use Flipgrid in a course they were teaching. But themes on why they would likely, or currently, use it focused on Flipgrid being easy to use, a good alternative to text-based discussions, and specifically on how discussions on Flipgrid can help build rapport, improve communication skills, and build community.

- It seems like a good alternative for text-discussion and could be useful to vary how learners respond or communicate in a discussion.

- I believe that, as a communication tool, it is much more intimate than a discussion forum and because of the asynchronous functionality and ease of use...

- I think it is a great format for discussions and the video helps bring in that community and conversations that sometimes can be misinterpreted/fall through the cracks in an entirely text-based discussion format.

- Flipgrid provides what online courses sometimes lack, a sense of real human interaction. Discussion boards can become dull, and people hide behind their keyboards.

- I have not come across a more fun, interactive, user friendly and easy way to engage in structured asynchronous video discussions online.

- I think Flipgrid gives everyone a voice and a face to the voice. I have used this in my classroom before and after students get used to, they typically enjoy it too. I think it helps them feel heard and allows them time to think and share on their own. I teach younger students so I feel like it would be more challenging to use this tool with them. However, I could see in the right circumstances, it could be effective.

However, students who were neutral or even disliked the use of Flipgrid explained that they did not find it appropriate for all age groups (whether that be younger K6 aged students or for adults in professional development settings), they found it glitchy, or simply had concerns about having themselves or their students record themselves. The following quotes capture some of these sentiments.

- I have used it but it becomes tough when my students say inappropriate things and $i$ have to watch EVERY VIDEO....

- I am not always comfortable in videos and I am sure many others are not either. It just does not seem necessary.

- It didn't allow the level of interaction to responding to comments. It was finicky with uploading videos and showing the correct previews.

- We have tried to use it at our institution but the platform is constantly updating and has frequent glitches. It became too much for faculty and most no longer use it. 
We then asked a series of questions to better understand students' perceptions of using Flipgrid. We specifically asked students to what degree they thought that Flipgrid helped improve social presence (i.e., the sense that others are "real" and "there"). The average response was 3.24 on a $0-4$ scale (see Table 1 ), with $83.54 \%$ reporting that they either agree or strongly agree that it did. Similarly, students reported that they agreed that Flipgrid helped them get to know their classmates better, with $82.28 \%$ agreeing or strongly agreeing that it did. Overall students reported that Flipgrid was easy to use $(M=3.42)$ and easy to respond to peers $(M=3.28)$.

We were specifically interested in whether using Flipgrid felt like busy work or if students would prefer to just use text-based discussions. When asked to what degree did they agree that responding to their peers' videos felt like busywork, only 27.75 (less than 1/3) strongly agreed or agreed, meaning that over $70 \%$ did not think it felt like busywork (see Table 1). Then when asked to what degree did they agree that they would prefer to simply use asynchronous discussion boards, $61.54 \%$ disagreed or strongly disagreed (see Table 1).

Table 1

Student Perceptions of Flipgrid (0-4 point scale)

\begin{tabular}{|c|c|c|c|c|c|c|c|}
\hline \multirow[b]{3}{*}{$\begin{array}{l}\text { How likely would you use Flipgrid } \\
\text { in an online course you were } \\
\text { teaching? }\end{array}$} & 4 & 3 & 2 & 1 & $\mathbf{0}$ & \multirow{3}{*}{$\begin{array}{c}M \\
3.14\end{array}$} & \multirow{3}{*}{$\begin{array}{l}\text { SD } \\
1.26\end{array}$} \\
\hline & \multicolumn{5}{|c|}{ [ Very Likely --_ery Unlikely] } & & \\
\hline & $46(58.23 \%)$ & $14(17.72 \%)$ & $9(11.39 \%)$ & $4(5.06 \%)$ & $6(7.59 \%)$ & & \\
\hline To what degree do you agree: & [ Strongl] & ly Agree ----- & 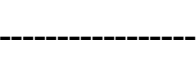 & --- Strongly $D$ & Disagree] & $M$ & SD \\
\hline I liked using Flipgrid in this course & $40(51.28 \%)$ & $19(24.36 \%)$ & $11(14.10 \%)$ & $4(5.13 \%)$ & $4(5.13 \%)$ & 3.12 & 1.15 \\
\hline $\begin{array}{l}\text { Flipgrid helped me get to know my } \\
\text { classmates better }\end{array}$ & $32(40.51 \%)$ & $33(41.77 \%)$ & $8(10.13 \%)$ & $2(2.53 \%)$ & $4(5.06 \%)$ & 3.10 & 1.03 \\
\hline $\begin{array}{l}\text { Flipgrid helped improve social } \\
\text { presence (i.e., the sense that others } \\
\text { are "real" and "there") in this course }\end{array}$ & $40(50.63 \%)$ & $26(32.91 \%)$ & $8(10.13 \%)$ & $2(2.53 \%)$ & $3(3.80 \%)$ & 3.24 & 1.0 \\
\hline Flipgrid was easy to use & $51(64.56 \%)$ & $16(20.25 \%)$ & $8(10.13 \%)$ & $2(2.53 \%)$ & $2(2.53 \%)$ & 3.42 & 0.96 \\
\hline $\begin{array}{l}\text { The instructor should have } \\
\text { responded to students in Flipgrid }\end{array}$ & $8(10.26 \%)$ & $18(23.08 \%)$ & $36(46.15 \%)$ & $12(15.38 \%)$ & $4(5.13 \%)$ & 2.8 & 0.99 \\
\hline $\begin{array}{l}\text { Responding to my peers' videos was } \\
\text { easy }\end{array}$ & $40(50.63 \%)$ & $27(34.18 \%)$ & $7(8.86 \%)$ & $4(5.06 \%)$ & $1(1.27 \%)$ & 3.28 & 0.92 \\
\hline $\begin{array}{l}\text { Responding to my peers' videos felt } \\
\text { like busy work }\end{array}$ & $7(8.86 \%)$ & $15(18.99 \%)$ & $22(27.85 \%)$ & $24(30.38 \%)$ & $11(13.92 \%)$ & 1.78 & 1.17 \\
\hline $\begin{array}{l}\text { I would have preferred simply using } \\
\text { asynchronous discussions boards in } \\
\text { this course }\end{array}$ & $8(10.26 \%)$ & $6(7.69 \%)$ & $16(20.51 \%)$ & $19(24.36 \%)$ & $29(37.18 \%)$ & 1.29 & 1.32 \\
\hline
\end{tabular}

Note: Two students did not answer a question. 


\section{Discussion}

The success of online learning begins and ends with interaction (Bernard et al., 2009; Mejia, 2020). While the type of interaction between students may look different based on the modality, the intention remains the same - have students engage with each other and the content in meaningful ways. Online instructors have explored different ways to recreate the types of interactions that take place in face-to-face classes - largely because interactive and engaging discussions have been linked to student satisfaction and learning in online courses (Dyer et al., 2018; Guo et al., 2019; Maddix, 2012; Mejia, 2020; Moore, 2014). One of the benefits of learning online is that instructors can leverage multimedia tools in ways that can help create interaction and engagement while also decreasing the transaction distance between learners (Mahmoudi \& Gronseth, 2019; Martin, Wang, \& Sadaf, 2018; Moore, 2014, 2016).

Many students report feeling isolated and distant when learning online; they miss the faceto-face connections and interactions they experience in traditional face-to-face classes (Kaufmann \& Vallade, 2020). These feelings can be exacerbated during text-based discussions commonly found in asynchronous discussion forums. Research suggests that video-based discussions might help alleviate some of these feelings (Clark et al., 2015; Delmas \& Moore; 2019; Gurjar, 2020; Mahmoudi \& Gronseth, 2019; Serembus \& Murphy, 2020).

In this study, we explored student perceptions of using Flipgrid to foster interaction in fully online courses. Online instructors often explore using new tools and strategies in their online courses. To successfully integrate a new tool, instructors must be cognizant of the technological demands and expectations that may be placed on students. It is also imperative that the tool adds instructional value. Often instructors will add a new tool and not seek feedback from students. To address these concerns, we surveyed students in three different graduate level courses to gain insight on their perceptions of using Flipgrid as a video-based discussion tool. We wanted to get a general idea of whether they liked using it or if they would prefer to simply use text-based discussions.

Overall, the majority of students reported that they liked using Flipgrid and found value in taking part in video-based asynchronous discussions, which aligns with some other research on using video-based asynchronous discussions (Ching \& Hsu, 2013; Delmas \& Moore, 2019; Lowenthal et al., 2020; Oliver et al., 2017; Pacansky-Brock, 2012, 2014). We found that students felt that the use of Flipgrid improved social presence and their feelings align with the benefits found by other researchers (Delmas \& Moore; 2019; Gurjar, 2020). The use of Flipgrid also allowed students to develop the types of peer connections that we were hoping for in online courses. This finding is consistent with what others have found with their own integrations of video-based discussions (Guo et al., 2019; Gurjar, 2020; Hall, 2015). The ease of use reported by the students also aligns with what other Flipgrid studies have reported (Iona, 2017). Some, though, expressed unease with being recorded, which aligns with previous research with VoiceThread in particular (see Pacansky-Brock, 2014). While Flipgrid does not allow text or audio posts or replies like VoiceThread, one can use a still shot, an avatar, or even have the camera face something else in their room (e.g., a laptop, a book, or even a stuffed animal) to enable them to post without showing their face. This could allow students to benefit from participating in the discussions but not feel any anxiety about being seen on camera. Flipgrid, in particular, also allows one to upload a video created on a different platform, thus giving students a bit more flexibility and creativity to present their ideas in a way that feels the most comfortable for them. 
Flipgrid was originally designed to be used in $\mathrm{K}-12$ classrooms. In many ways, this is both a blessing and a curse for integrating it into higher education settings. It is a blessing in that the interface is simple and easy to use, as many students in our study commented that they appreciated. But it is also a curse in that there are some features, such as the stickers and emojis, that can feel childish to some older students. Luckily, when instructors set up a Flipgrid, they can decide to enable or disable the options for students to use stickers and emojis. And while some students in our study specifically mentioned this as being a bad thing, other students commented that they enjoyed the opportunity to be more creative and show their personalities in their replies. Individual instructors will need to determine for themselves and for their students the best way to manage these two competing interests.

\section{Conclusions}

Video, whether asynchronous or synchronous, is not a panacea. Rather, it is how video is used that matters the most. With that said, there are some inherent affordances with video and specifically asynchronous video - one of these being the ability to see and hear one another. Flipgrid is a relatively new web-based application that simplifies the process of having asynchronous video-based discussions. We set out to investigate students' perceptions of using Flipgrid in fully online courses. Due to the sample size, the results should not be generalized.

Very little research, though, has been conducted on students' perceptions of using Flipgrid. For instance, do students really want to see each other? Are students really not happy with asynchronous text-based online discussions? Our results suggest that Flipgrid was easy to use, students in this sample enjoyed using it, and it helped them get to know their peers in an efficient manner. However, additional research needs to be conducted on Flipgrid. For instance, is there a relationship between students' perceptions of Flipgrid and their perceptions of social presence and community in a course? What are online instructors' perceptions of Flipgrid? How can Flipgrid be used to improve student outcomes? This research, though, is an important first step in investigating a new communication technology, one that holds promise to help improve how students interact and engage with each other not only in fully online courses but in blended, face-to-face, or even emergency remote teaching situations. 


\section{References}

Aloni, M., \& Harrington, C. (2018). Research based practices for improving the effectiveness of asynchronous online discussion boards. Scholarship of Teaching and Learning in Psychology, 4(4), 271-289. http://doi.org/10.1037/st10000121

Arend, B. (2009). Encouraging critical thinking in online threaded discussions. The Journal of Educators Online, 6(1), 1-23. https://doi.org/10.9743/JEO.2009.1.1

Bernard, R. M., Abrami, P. C., Borokhovski, E., Wade, C. A., Tamim, R. M., Surkes, M. A., \& Bethel, E. C. (2009). A meta-analysis of three types of interaction treatments in distance education. Review of Educational Research, 79(3), 1243-1289. http://dx.doi.org/10.3102/0034654309333844

Borup, J., West, R. E., \& Graham, C. R. (2012). Improving online social presence through asynchronous video. The Internet and Higher Education, 15(3), 195-203. http://dx.doi.org/10.1016/j.iheduc.2011.11.001

Borup, J., West, R. E., \& Graham, C. R. (2013). The influence of asynchronous video communication on learner social presence: A narrative analysis of four cases. Distance Education, 34(1), 48-63. http://dx.doi.org/10.1080/01587919.2013.770427

Boston, W., Díaz, S. R., Gibson, A. M., Ice, P., Richardson, J., \& Swan, K. (2009). An exploration of the relationship between indicators of the Community of Inquiry framework and retention in online programs. Journal of Asynchronous Learning Networks, 13(3), 67-83. http://dx.doi.org/10.24059/olj.v13i3.1657

Boston, W. E., Ice, P., \& Gibson, A. M. (2011). Comprehensive assessment of student retentionin online learning environments. Online Journal of Distance Learning Administration, 14(4). http://www.westga.edu/ distance/ojdla/spring141/boston_ice_gibson141.html

Ching, Y. -H. (2014). Exploring the impact of role-playing on peer feedback in an online case-based learning activity. The International Review of Research in Open and Distributed Learning, 15(3). http://dx.doi.org/10.19173/irrodl.v15i3.1765

Ching, Y.-H., \& Hsu, Y.-C. (2013). Collaborative learning using VoiceThread in an online graduate course. Knowledge Management \& E-Learning, 5(3), 298-314. https://doi.org/10.34105/j.kmel.2013.05.021

Clark, C., Strudler, N., \& Grove, K. (2015). Comparing asynchronous and synchronous video vs. text based discussions in an online teacher education course. Online Learning, 19(3), 48-70. http://dx.doi.org/10.24059/olj.v19i3.668

Delmas, P. M., \& Moore, P. R. (2019). Student perceptions of video-based discussions in online and blended learning. Proceedings of the E-Learn 2019 Annual Conference (pp. 1280-1286). Association for the Advancement of Computing in Education.

Doherty, W. (2006). An analysis of multiple factors affecting retention in web-based community college courses. Internet and Higher Education, 9, 245-255.

Dunlap, J. C., \& Lowenthal, P. R. (2011). VoiceThread Virtuosity. In P. Shank (Ed.), The online learning idea book: Proven ways to enhance technology-based and blended learning (Vol. 2, pp. 288-292). Pfeiffer.

Dyer, T., Aroz, J., \& Larson, E. (2018). Proximity in the online classroom: Engagement, relationships, and personalization. Journal of Instructional Research, 7, 108-118. 
Garrett Dikkers, A., Whiteside, A. L., \& Lewis, S. (2012). Get present: Build community and connectedness online. Learning \& Leading with Technology, 40(2), 22-25.

Garrison, D. R., Anderson, T., \& Archer, W. (2001). Critical thinking, cognitive presence, and computer conferencing in distance education. American Journal of Distance Education, 15(1), 7-23. http://doi.org/10.1080/08923640109527071

Gerbensky-Kerber, A. (2017). Creating a structured practice space with online mini-speeches. Communication Teacher, 31(2), 70-73. https://doi.org/10.1080/17404622.2017.1285409

Glasow, P. A. (2005). Fundamentals of survey research methodology. Mitre.

Gray, J. A., \& DiLoreto, M. (2016). The effects of student engagement, student satisfaction, and perceived learning in online learning environments. NCPEA International Journal of Educational Leadership Preparation, 11(1), 98-119.

Green, T., \& Green, J. (2018). Flipgrid: Adding voice and video to online discussions. TechTrends, 62, 128-130. http://doi.org/10.1007/s11528-017-0241-x

Gurjar, N. (2020). Reducing transactional distance with synchronous and asynchronous video-based discussions in distance learning. Proceedings of the SITE 2020: Society for Information Technology \& Teacher Education International Conference (pp. 268-272). Association for the Advancement of Computing in Education.

Guo, C., Chen, X., \& Hou, Y. (2019). A case study of students' participation and knowledge construction in two online discussion settings. Proceedings of the 2019 4th International Conference on Distance Education and Learning (pp. 45-49). Association for Computing Machinery. https://doi.org/10.1145/3338147.3338177

Hall, P. K. (2015). Using a video response tool for course assignments. North American Colleges and Teachers of Agriculture (NACTA) Journal, 59(4), 355-356.

Harasim, L. (1987). Teaching and learning on-line: Issues in computer-mediated graduate courses. Canadian Journal of Educational Communication, 16(2), 117-135.

Howard, C. D., \& Myers, R. (2010). Creating Video-annotated discussions: An asynchronous alternative. International Journal of Designs for Learning, 1(1). https://doi.org/10.14434/ijdl.v1i1.853

Hrastinski, S. (2008). Asynchronous and synchronous e-learning. EDUCAUSE Quarterly, 31(4), 5155.

Iona, J. (2017). Flipgrid. School Librarian, 65(4), 211-212.

Johnson, C. M. (2016). Rethinking online discourse: Improving learning through discussions in the online classroom. Education and Information Technologies, 21(6), 1483-1507. http://dx.doi.org/10.1007/s10639-015-9395-3

Johnson, G. (2008). The relative learning benefits of synchronous and asynchronous text-based discussion. British Journal of Educational Technology, 39(1), 166-169. http://dx.doi.org/10.1111/j.1467-8535.2007.00739.x

Jones-Roberts, C. (2018). Increasing social presence online: Five strategies for instructors. Distance Learning, 15(2), 47-50. 
Kaufmann, R., \& Vallade, J. I. (2020). Exploring connections in the online learning environment: student perceptions of rapport, climate, and loneliness. Interactive Learning Environments. https://doi.org/10.1080/10494820.2020.1749670

Khan, A., Egbue, O., Palkie, B., \& Madden, J. (2017). Active learning: Engaging students to maximize learning in an online course. Electronic Journal of E-Learning, 15(2), 107-115.

Koricich, A. (2013). Technology review: Multimedia discussions through VoiceThread. The Community College Enterprise, 19, 76-79.

Kwon, K., Park, S. J., Shin, S., \& Chang, C. Y. (2019). Effects of different types of instructor comments in online discussions. Distance Education, 40(2), 226-242. http://dx.doi.org/10.1080/01587919.2019.1602469

Leech, N. L., \& Onwuegbuzie, A. J. (2007). An array of qualitative data analysis tools: A call for data analysis triangulation. School Psychology Quarterly, 22(4), 557-584. http://dx.doi.org/10.1037/1045-3830.22.4.557

Lowenthal, P. R. (2010). The evolution and influence of social presence theory on online learning. In T. T. Kidd (Ed.), Online education and adult learning: New frontiers for teaching practices (pp. 124-139). IGI Global. http://dx.doi.org/10.4018/978-1-60566-984-7.ch010

Lowenthal, P. R., Borup, J., West, R. E., \& Archambault, L. (2020). Thinking beyond Zoom: Using asynchronous video to maintain connection and engagement during the COVID-19 pandemic. Journal of Technology and Teacher Education, 28(2), 1-9.

Lowenthal, P. R., \& Mulder, D. (2017). Social presence and communication technologies: Tales of trial and error. In A. Whiteside, A. Garrett Dikkers, \& K. Swan, (Eds.), Social presence in online learning: Multiple perspectives on practice and research (pp. 32-44). Stylus.

Lowenthal, P., West, R., Archambault, L., \& Borup, J. (2020, August). Engaging students through asynchronous video-based discussions in online courses. EDUCAUSE Review. https://er.educause.edu/articles/2020/8/engaging-students-through-asynchronous-videobased-discussions-in-online-courses

Ludwig-Hardman, S., \& Dunlap, J. C. (2003). Learning support services for online students: Scaffolding for success. International Review of Research in Open and Distance Learning, 4(1). https://doi.org/10.19173/irrodl.v4i1.131

Maddix, M. A. (2012). Generating and facilitating effective online learning through discussion. Christian Education Journal, 9(2), 372-385. http://dx.doi.org/10.1177/073989131200900209

Mahmoudi, L., \& Gronseth, S. (2019). Video-based discussion: Promoting presence through interactions in online higher education courses. In E. Ossiannilsson (Ed.), Ubiquitous inclusive learning in a digital era: Advances in educational technologies and instructional design (1st ed., pp. 128-153). IGI Global. http://doi.org/10.4018/978-1-5225-6292-4.ch006

Mango, O. (2019). Students' perceptions and attitudes toward the use of Flipgrid in the language classroom. In K. Graziano (Ed.), Proceedings of the Society for Information Technology \& Teacher Education International Conference (pp. 1970-1973). Association for the Advancement of Computing in Education.

Martin, F., Wang, C., \& Sadaf, A. (2018). Student perception of helpfulness of facilitation strategies that enhance instructor presence, connectedness, engagement and learning in online courses. The Internet and Higher Education, 37, 52-65. http://doi.org/10.1016/j.iheduc.2018.01.003 
Mejia, C. (2020). Using VoiceThread as a discussion platform to enhance student engagement in a hospitality management online course. Journal of Hospitality, Leisure, Sport \& Tourism Education, 26, 1-11. https://doi.org/10.1016/j.jhlste.2019.100236

Meyer, K. A. (2003). Face-to-face versus threaded discussions: The role of time and higher-order thinking. Journal of Asynchronous Learning Networks, 7(3), 55-65.

Moore, R. L. (2014). Importance of developing community in distance education courses. TechTrends, 58(2), 20-24. http://doi.org/10.1007/s11528-014-0733-x

Moore, R. L. (2016). Interacting at a distance: Creating engagement in online learning environments. In L. Kyei-Blankson, J. Blankson, E. Ntuli, \& C. Agyeman (Eds.), Handbook of research on strategic management of interaction, presence, and participation in online courses (pp. 401425). IGI Global. http://doi.org/10.4018/978-1-4666-9582-5.ch016

Nandi, D., Hamilton, M., \& Harland, J. (2012). Evaluating the quality of interaction in asynchronous discussion forums in fully online courses. Distance Education, 33(1), 5-30. https://doi.org/10.1080/01587919.2012.667957

Oliver, K. M., Houchins, J. K., Moore, R. L., \& Wang, C. (2020). Informing makerspace outcomes through a linguistic analysis of written and video-recorded project assessments. International Journal of Science and Mathematics Education. https://doi.org/10.1007/s10763-020-10060-2

Oliver, K. M., Moore, R. L., \& Evans, M. A. (2017). Establishing a virtual makerspace for an online graduate course: A design case. International Journal of Designs for Learning, 8(1), 112123. https://doi.org/10.14434/ijdl.v8i1.22573

Pacansky-Brock, M. (2012). Best practices for teaching with emerging technologies. Routledge.

Pacansky-Brock, M. (2014). Learning out loud: Increasing voluntary voice comments in online classes. In P. R. Lowenthal, C. S. York, \& J. C. Richardson (Eds.), Online learning: Common misconceptions, benefits and challenges (pp. 99-114). Nova Science Publishers.

Picciano, A. G. (2002). Beyond student perceptions: Issues of interaction, presence, and performance in an online course. Journal of Asynchronous Learning Networks, 6(1), 21-40. http://dx.doi.org/10.24059/olj.v6i1.1870

Pinsk, R., Curran, M. J., Poirier, R., \& Coulson, G. (2014). Student perceptions of the use of studentgenerated video in online discussions as a mechanism to establish social presence for nontraditional students: A case study. Issues in Information Systems, 15(I), 267-276.

Poll, K., Widen, J., \& Weller, S. (2014). Six instructional best practices for online engagement and retention. Journal of Online Doctoral Education, 1(1), 56-72.

Richardson, J. C., Maeda, Y., Lv, J., \& Caskurlu, S. (2017). Social presence in relation to students' satisfaction and learning in the online environment: A meta-analysis. Computers in Human Behavior, 71, 402-417. http://dx.doi.org/10.1016/j.chb.2017.02.001

Romero-Hall, E., \& Vicentini, C. R. (2017). Multimodal interactive tools for online discussions and assessment. In P. Vu, S. Fredrickson, \& C. Moore (Eds.), Handbook of research on blended learning pedagogies and professional development in higher education (pp. 85-105). IGI Global. http://doi.org/10.4018/978-1-5225-1851-8.ch005

Rourke, L., Anderson, T., Garrison, D. R., \& Archer, W. (1999). Assessing social presence in asynchronous text-based computer conferencing. The Journal of Distance Education, 14(2), $50-71$. 
Rovai, A. P. (2002). Development of an instrument to measure classroom community. Internet and Higher Education, 5(3), 197-211. http://dx.doi.org/10.1016/S1096-7516(02)00102-1

Saçak, B., \& Kavun, N. (2020). Rethinking Flipgrid and VoiceThread in the context of online collaborative learning theory. In E. Alqurashi (Ed.), Handbook of research on fostering student engagement with instructional technology in higher education (pp. 211-228). IGIGlobal. https://doi.org/10.4018/978-1-7998-0119-1.ch012

Saldana, J. (2016). The coding manual for qualitative researchers (3rd ed.). Sage.

Serembus, J. F., \& Murphy, J. (2020). Creating an engaging learning environment through video discussions. Nurse Educator, 45(2), 68-70. https://doi.org/10.1097/NNE.0000000000000701

Skylar, A. A. (2009). A comparison of asynchronous online text-based lectures and synchronous interactive web conferencing lectures. Issues in Teacher education, 18(2), 69-84.

Stodel, E. J., Thompson, T. L., \& MacDonald, C. J. (2006). Learners' perspectives on what is missing from online learning: Interpretations through the community of inquiry framework. The International Review of Research in Open and Distributed Learning, 7(3). https://doi.org/10.19173/irrodl.v7i3.325

Song, L., Singleton, E. S., Hill, J. R., \& Koh, M. H. (2004). Improving online learning: Student perceptions of useful and challenging characteristics. Internet and Higher Education, 7, 5970. https://doi.org/10.1016/j.iheduc.2003.11.003

Trespalacios, J., \& Rand, J. (2015). Using asynchronous activities to promote sense of community and learning in an online course. International Journal of Online Pedagogy and Course Design, 5(4), 1-13. http://dx.doi.org/10.4018/IJOPCD.2015100101

Whiteside, A. L. (2015). Introducing the Social Presence Model to explore online and blended learning experiences. Online Learning Journal, 19(2). http://dx.doi.org/10.24059/olj.v19i2.453

Whiteside, A. L., Garrett Dikkers, A., \& Lewis, S. (2014). The power of social presence for learning. EDUCAUSE Review Online. http://er.educause.edu/articles/2014/5/the-power-of-socialpresence-for-learning

Woods, K., \& Bliss, K. (2016). Facilitating successful online discussions. Journal of Effective Teaching, 16(2), 76-92. 